\title{
Mathematical Modelling and Experimental Investigation of a Low Temperature Proton Exchange Membrane Fuel Cell
}

\author{
Keoagile Mogorosi ${ }^{1,2 *}$, M. Tunde Oladiran${ }^{1}$, Edward Rakgati2 $^{2}$ \\ ${ }^{1}$ Department of Mechanical, Energy and Industrial Engineering, Botswana International University of Science and Technology, \\ Palapye, Botswana \\ ${ }^{2}$ Botswana Institute for Technology Research and Innovation, Gaborone, Botswana \\ Email: *kemogorosi@gmail.com
}

How to cite this paper: Mogorosi, K., Oladiran, M.T. and Rakgati, E. (2020) Mathematical Modelling and Experimental Investigation of a Low Temperature Proton Exchange Membrane Fuel Cell. Energy and Power Engineering, 12, 653-670. https://doi.org/10.4236/epe.2020.1211039

Received: July 24, 2020

Accepted: November 21, 2020

Published: November 24, 2020

Copyright $\odot 2020$ by author(s) and Scientific Research Publishing Inc. This work is licensed under the Creative Commons Attribution International License (CC BY 4.0).

http://creativecommons.org/licenses/by/4.0/

\begin{abstract}
This paper presents dynamic modeling of $1000 \mathrm{~W}$ EC6C Proton Exchange Membrane fuel cell (PEMFC) manufactured by Edibon. Experiments were carried out to investigate the performance of the system and a dynamic electrical model was implemented in Matlab/Simulink. The simulation model was able to predict efficiency, power and fuel cell potential. The model was also tested with load variations to find out the real time responses. The results were validated by experimental findings. The comparison showed that the model was effective and could be used in optimization of the fuel cell system operated at low temperatures under 80 degrees.
\end{abstract}

\section{Keywords}

Fuel Cell, Modeling, Experiment, Simulink, Energy

\section{Introduction}

The world is currently faced with environmental concerns such as harmful emissions into the atmosphere from combustion of fossil fuels for energy needs. Also, hydrocarbon fuels are finite because they are not renewable. These concerns justify the need for extensive research and development of alternative inexhaustible energy sources. Renewable energy options include solar, wind, biofuels and fuel cells. Fuel Cells are potential replacement for fossil fuel-based energy sources because of their numerous advantages such as continuous availability of power generation. A fuel cell is an electrochemical device that combines a fuel (hydrogen) and an oxidizing agent (oxygen), and converts the chemical energy directly 
into electrical power, water and waste heat. They are usually categorized according to type of electrolyte used which determines the operating temperature of a system.

Although Fuel Cells are already commercially available, they are highly expensive for compact applications such as portable power sources, small-scale power generation and transportation [1]. There are six types of Fuel Cells, namely the Alkaline Fuel Cell (AFC), Phosphoric Acid Fuel Cell (PAFC), Molten Carbonate Fuel Cell (MCFC), Solid Oxide Fuel Cell (SOFC), Proton Exchange Membrane Fuel Cell (PEMFC) and Direct Methanol Fuel Cell (DMFC). A summary of the characteristics of fuel cells are presented in Table 1.

Although the fuel cells are a promising application they still face competition from other systems especially in automobile application. Competition is one of the barriers to widespread commercialization. Table 2 shows the comparison of different applications including the hydrogen fuel cell.

Table 1. Characteristics of fuel cell types [2].

\begin{tabular}{|c|c|c|c|c|}
\hline Fuel Cell Type & Electrolyte Type & Operating Temperature & Efficiency & Fuel \\
\hline Alkaline Fuel Cell (AFC) & $\begin{array}{l}\text { Potassium hydroxide }(\mathrm{KOH}) \\
\text { solution }\end{array}$ & Room temperature to $90^{\circ} \mathrm{C}$ & $60 \%-70 \%$ & $\mathrm{H}_{2}-\mathrm{O}_{2}$ \\
\hline $\begin{array}{l}\text { Proton Exchange Membrane } \\
\text { Fuel Cell (PEMFC) }\end{array}$ & Proton Exchange Membrane & Room temperature to $80^{\circ} \mathrm{C}$ & $40 \%-60 \%$ & $\mathrm{H}_{2}-\mathrm{O}_{2}$ or Air \\
\hline $\begin{array}{l}\text { Direct Methanol Fuel Cell } \\
\text { (DMFC) }\end{array}$ & Proton Exchange Membrane & Room temperature to $130^{\circ} \mathrm{C}$ & $20 \%-30 \%$ & $\mathrm{CH}_{2} \mathrm{OH}-\mathrm{O}_{2}$ or Air \\
\hline $\begin{array}{l}\text { Phosphoric Acid Fuel Cell } \\
\text { (PAFC) }\end{array}$ & Phosphoric acid & $160^{\circ} \mathrm{C}-220^{\circ} \mathrm{C}$ & $55 \%$ & $\begin{array}{l}\text { Natural Gas, Biogas, } \mathrm{H}_{2}-\mathrm{O}_{2} \text { or } \\
\text { Air }\end{array}$ \\
\hline $\begin{array}{l}\text { Molten Carbonate Fuel Cell } \\
\text { (MCFC) }\end{array}$ & $\begin{array}{l}\text { Molten mixture of alkali } \\
\text { metal carbonates }\end{array}$ & $620^{\circ} \mathrm{C}-660^{\circ} \mathrm{C}$ & $65 \%$ & $\begin{array}{l}\text { Natural Gas, Biogas, Coal gas, } \\
\mathrm{H}_{2}-\mathrm{O}_{2} \text { or Air }\end{array}$ \\
\hline $\begin{array}{l}\text { Solid Oxide Fuel Cell } \\
\text { (SOFC) }\end{array}$ & $\begin{array}{l}\text { Oxide ion conducting } \\
\text { ceramic }\end{array}$ & $800^{\circ} \mathrm{C}-1000^{\circ} \mathrm{C}$ & $60 \%-65 \%$ & $\begin{array}{l}\text { Natural Gas, Biogas, Coal gas, } \\
\mathrm{H}_{2}-\mathrm{O}_{2} \text { or Air }\end{array}$ \\
\hline
\end{tabular}

Table 2. Fuel cell competition with other systems.

\begin{tabular}{|c|c|c|c|c|}
\hline \multicolumn{5}{|c|}{ Comparison of Different Vehicle Types } \\
\hline & Gasoline ICE & Gasoline Hybrid & $\mathrm{H}_{2} \mathrm{CI}$ & $\mathrm{H}_{2}$ Fuel Cell \\
\hline Engine Type & Spark ignition & Spark ignition \& Electric motor & CI (with electric motor) & Fuel cell \& electric motor \\
\hline $\begin{array}{l}\text { Average engine } \\
\text { efficiency }\end{array}$ & $\sim 30 \%$ & $\sim 30 \%$ & $\sim 40 \%$ & $\sim 55 \%$ \\
\hline $\begin{array}{l}\text { Max engine } \\
\text { efficiency }\end{array}$ & $32.5 \%$ & $32.5 \%$ & $\sim 40 \%$ & $\sim 65 \%$ \\
\hline Size-ability & $\begin{array}{l}\text { As much power as } \\
\text { needed, at the cost of } \\
\text { mpg }\end{array}$ & $\begin{array}{l}\text { Efficiency improvements over gas } \\
\text { ICEs are mostly lost with increased } \\
\text { power }\end{array}$ & $\begin{array}{l}\text { Efficiency losses or higher } \\
\text { emission control costs to } \\
\text { increase power }\end{array}$ & $\begin{array}{l}\text { Increasing power may be } \\
\text { expensive, requiring } \\
\text { additional FCs }\end{array}$ \\
\hline Cost of Fuel & Currently low & Currently low & $\begin{array}{l}\text { Currently high; but may be } \\
\text { slightly lower than FCVs }\end{array}$ & Currently high \\
\hline $\begin{array}{l}\text { Criteria Pollutant } \\
\text { Emissions }\end{array}$ & $\begin{array}{l}\text { Meets emission } \\
\text { standards }\end{array}$ & Lower than gasoline ICE & Likely low, some $\mathrm{NO}_{\mathrm{x}}$ & Very low or none \\
\hline State of technology & developed & developed, and in diffusion stage & Could be developed quickly & Earlier in the research process \\
\hline
\end{tabular}


This paper presents the study performed on a PEMFC at the Botswana International University of Science and Technology (BIUST) and the results were compared with those from a dynamic model using Matlab/Simulink software.

\section{Principles of PEMFC}

Proton exchange membrane fuel cells are being developed mostly for transport, stationary and portable applications. The PEMFC's distinctive features include operation at low temperatures of (less than $100^{\circ} \mathrm{C}$ ), allowing quick start-ups and immediate responses to changes in power demand. PEMFC utilizes platinum-based catalysts on the anode to split hydrogen into protons and electrons. The protons pass through the membrane to the cathode and combine with oxygen to produce water. The electrons pass through the external circuit creating a current flow and eventually rejoining the hydrogen protons and oxygen to form water as the by product. The PEMFC is shown in Figure 1 .

Compared to other fuel cell types, Proton exchange membrane (PEM) types are more promising due to their comparatively high-power density and high efficiency. PEMFCs are complex systems comprising of processes, namely electrochemical reactions, thermal transport, mass transport, electron transfer, and proton transfer. Conductance of gas, electrons, and protons must be optimized to provide efficient transport to and from the electrochemical reactions [1]. Ion conduction as one of the transport processes is a thermally activated procedure and its magnitude varies significantly depending on the type of material, electrolyte which may be either liquid or solid, and hence determines the temperature at which the fuel cell is operated [3]. For the systems to function and accomplish these processes, different components are incorporated to accomplish the tasks. The basic structure of PEM fuel cell comprises of gas channels, gas diffusion layers, catalyst layers, and the electrolyte layer. Figure 2 illustrates the schematic layout of typical PEM fuel cell.

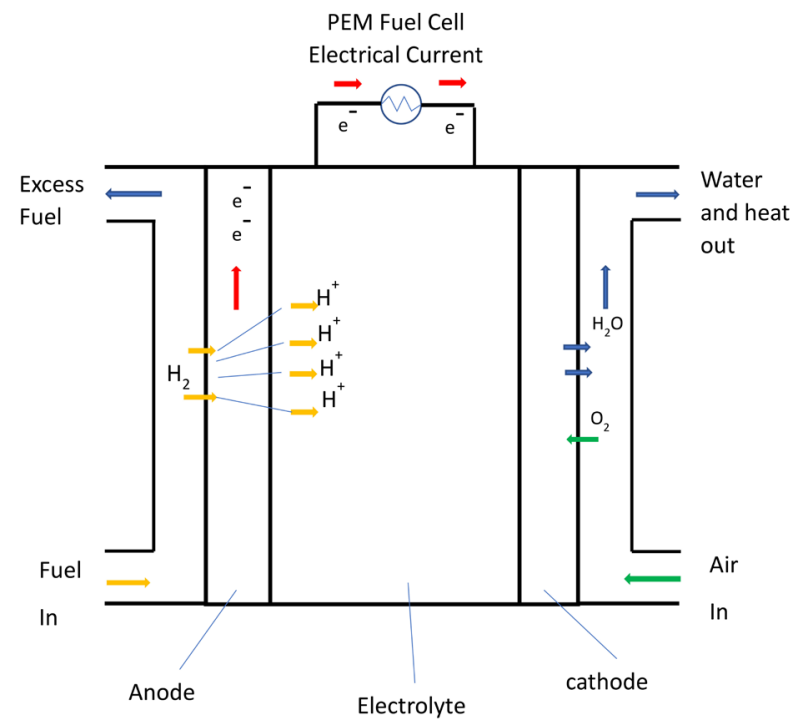

Figure 1. Illustration of PEM fuel cell. 


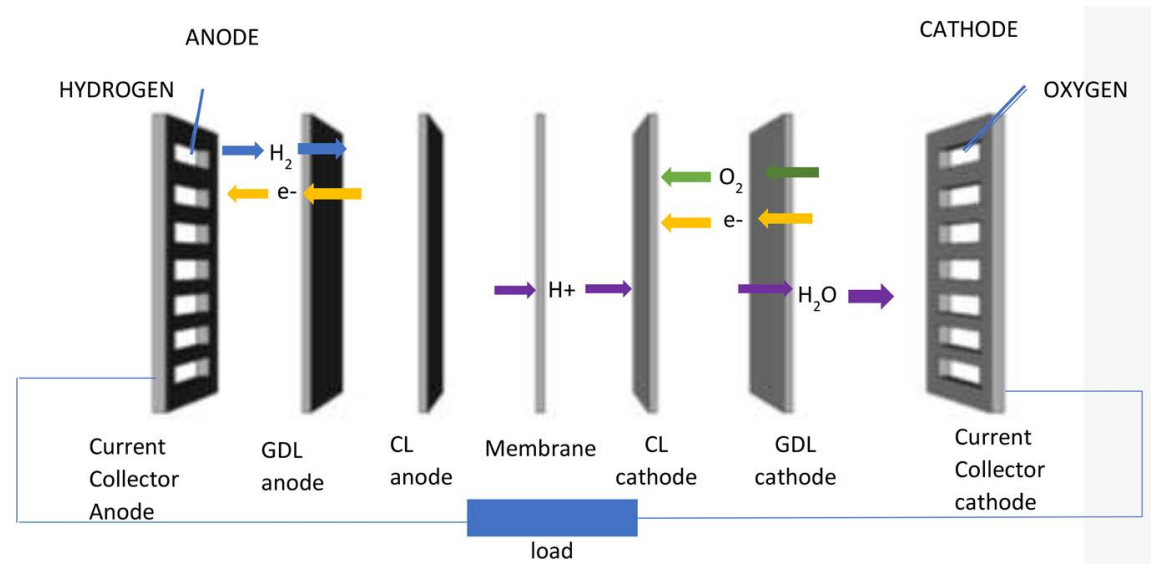

Figure 2. Schematic of typical PEM fuel cell.

\section{Operation of PEMFC}

The principle of operation is such that at the anode, $\mathrm{H}_{2}$ fuel is oxidized releasing electrons and generating protons. The electrons and protons then flow respectively through the external circuit and proton exchange membrane inserted tightly between the anode and the cathode, to the cathode. At the cathode they combine with the dissolved oxidant $\mathrm{O}_{2}$ to produce water and heat. The fuel cell processes facilitate the reactants moving from the bipolar gas channel plates into the GDLs. The function of the GDLs to spread the reactants over the catalyst layer with more even distribution. At the catalyst layer the reactants are then transported by diffusion and advection for an electrochemical reaction. The PEM can transport the protons and dissolved water, but gases cannot permeate through.

The components shown in Figure 2 include current collector (CC) plates (cathode and anode), gas diffusion layers (GDL), catalyst layers (CL), and the membrane. In this fuel cell, platinum is used to efficiently catalyze the oxidation of hydrogen and reduction of oxygen. Table 3 shows the common materials used in PEMFC.

\section{Literature Review}

There are several dynamic models and studies carried out on PEMFC. [4] Saadi et al. (2017) implemented a model in Matlab/Simulink ${ }^{\mathrm{mm}}$ environment. In their study they found that Impedance model can serve as a standard analytical diagnostic tool for fuel cell evaluation and characterization. Nguyen et al. (2016) [5] investigated the dynamic response of a fuel cell with simulated reformate gas. The dynamic response of the fuel cell stack was measured by changing the current from 0.09 to $0.18 \mathrm{~A} / \mathrm{cm}^{2}$ and back to $0.09 \mathrm{~A} / \mathrm{cm}^{2}$. The model compared well with some of the cells in the stack while other cells had typically lower voltage levels during dynamic operation. Zaidi et al. (2014) [6] presented a Simulink model which included various dynamic operating conditions like changes in load current, pressures of input reactant gases and the cell operating temperature. The 
Table 3. Fuel cell components and typical material.

\begin{tabular}{cc}
\hline Component & Material \\
\hline Current collectors & Titanium, copper etc \\
GDLs & Carbon paper/cloth \\
PEM & Nafion composites \\
Catalyst Layer & Platinum/platinum alloys \\
\hline
\end{tabular}

simulation was designed to be very user-friendly when the various dynamic conditions were altered and the responses observed. Azri et al. (2014) [7] also presented a Matlab/Simulink model based on a fuel cell Horizon H-500 stack. The performance of power, voltage and the three losses (activation, concentration and ohmic) were visualized. The authors found that the ambient temperature and input gas pressure are affecting the performance of the PEMFC power.

El Monem et al. (2014) [8] described a model of PEM Fuel Cells which can be used in different dynamic environments such as in vehicle applications. The performance of the model showed fast response to load variations.

Edwards et al. (2016) [9] experimentally studied dynamic responses of a typical single-cell PEMFC with a thin Membrane Electrode Assembly (MEA) to step changes in current load. The study examined resistance and voltage transient responses. The work showed that a very simplified understanding of the physics of the MEA explains some of the variations in amplitudes and timescales. The model fitted transient responses by mono-exponential functions for the resistance and tri-exponential functions for the voltage. Their results provide an empirical basis for the estimation of the magnitude of temporary voltage loss, which is expected with sudden load changes, as well as a systematic method for the analysis of experimental data. The application of their model is limited to thin membranes with low to moderate humidity gases, and with adequately high reactant-gas stoichiometry.

In another study Martin I., et al. (2014) [10] describes modelling of a commercial $1.2 \mathrm{~kW}$ FC capable of predicting the fuel cell voltage and operating temperature, based on the current required and the ambient temperature. The model was based on both the electrical and the thermal one. The paper proposed the electrical model based on the sum of the thermodynamic and activation, ohmic, concentration and double layer phenomena taking place in the fuel cell. The consumption of the peripherals was also modelled whilst the thermal model proposed was based on the fuel cell thermal energy balance, and heat generation, dissipation mechanisms and fuel cell thermal capacity were taken account for. In this study an experimental characterization was performed for the electrical and thermal operation alike, making it possible to obtain the parameters for the fuel cell models. Matlab Simulink was used to implement the models. The validation for the models was performed through running experiment of $4.6 \mathrm{~kW}$ rated 
PEM fuel cell located at the Public University of Navarre.

Abdin Z., et al. [11] also reports on a study of a steady-state one dimensional model of a PEM fuel cell based on physical parameters. This model relates PEM fuel cell performance to fundamental physical parameters, and it can be applied in developing improved electrodes to reduce the activation overpotential, by incorporating the measured or predicted characteristics of new electrocatalyst materials into the relevant ancillaries. The paper reports that the model was validated in two ways; First, published experimental cell polarization data compared very well, with five free model parameters (charge transfer coefficients, roughness factor and reference exchange current densities) related to physical parameters whose values are difficult to estimate reliably. The comparison showed that the fitted values of these parameters were within the expected ranges. It also showed that the model was able to track changes in the polarization curve due to varying temperature and pressure, without altering the model parameters. Second this model was also compared to three published models with varying degrees of complexity but with similar objectives.

\section{Methodology and Experiment Setup}

This paper presents the development of a dynamic mathematical model of the Fuel Cell using the Matlab/Simulink software environment. The model was run to find the performance prediction of the Fuel Cell, extract data to produce different graphs such as polarization, power and efficiency curves.

Then experiments were performed to validate the model. The EC6C equipment used was acquired from a Spanish company Edibon (Figure 3). The unit comprises of a stack of PEMFC with a rated power of $1000 \mathrm{~W}$. It has 72 cells with channeled plates to allow airflow through the membrane. The cells are self-humidifying and therefore do not require external humidification. The stack has integrated fans to provide cooling for the good operation.

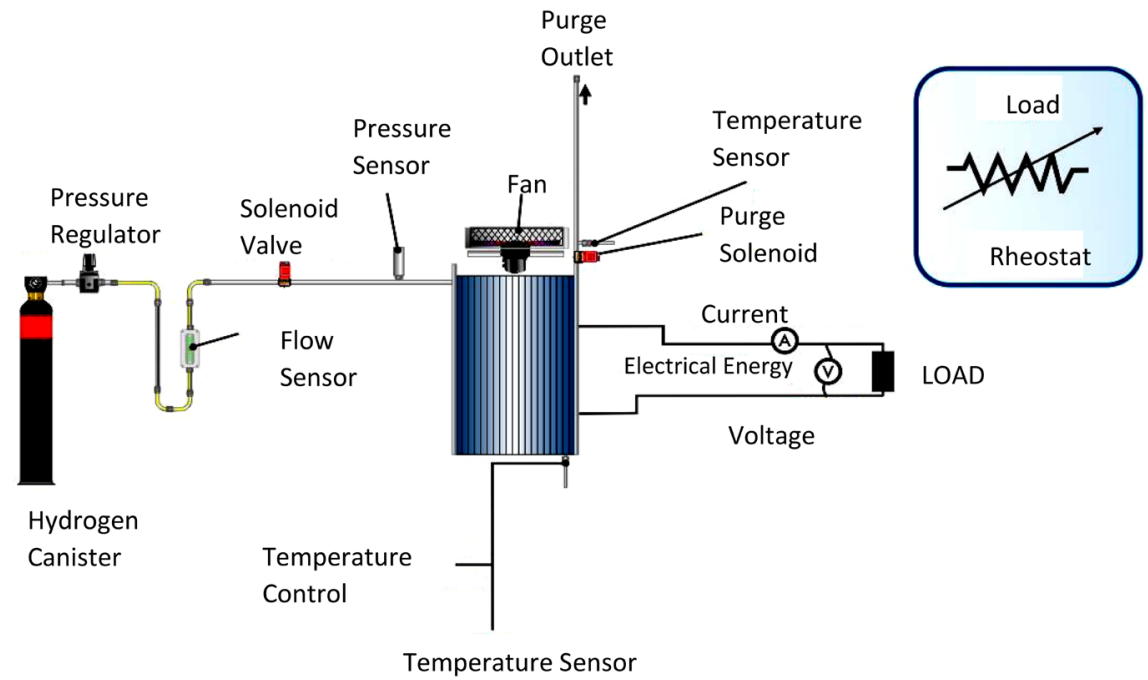

Figure 3. Edibon fuel cell unit. 
The equipment is versatile to perform many experiments and was used for the following tests: fuel cell efficiency, polarization curve of the fuel cell, voltage and current density characteristics of the fuel cell and the influence of hydrogen on the electric power generation. The PEMFC system is powered by hydrogen from a canister which can run a set of experiments lasting about 2 hours before recharging by electrolysis. Temperature sensors, air flow sensors, fan actuator, resistance actuator and differential pressure sensor are also incorporated in the unit.

The EC6C unit is supplied with pressure regulator which is used to control pressure within the range for the experiments. The other variable parameter was the fuel flow rate which was regulated by a valve. The interface is fitted with a rheostat which helps in regulating the load manually by varying the step current. The software provided with the unit has the ability to record the experimental results and be downloaded later. Analysis of the results was carried out and used to validate the Simulink model.

\section{Modeling of PEMFC}

The PEMFC model consists of five regions, namely the flow channels at the anode and cathode, the diffusion layers on the cathode and anode sides, and the PEM as shown in Figure 2.

\subsection{Model Assumptions}

Analysis and modelling of fuel cells presents a complex flow phenomenon and therefore assumptions are made to simplify the simulations. The following assumptions were made;

1) Individual cells perform similarly and therefore lumped as a stack.

2) Gases are ideal

3) Temperature of the gases inside the stack is the same as the stack temperature.

4) Pure hydrogen is assumed

5) Constant pressures in the gas flow channels and

6) The by-product is liquid water only.

\subsection{Modelling}

The electrical analogy of the fuel cell is depicted in Figure 4. The electrochemical process in the PEMFC shows many losses because of the activation polarization, ohmic polarization and concentration polarization. The losses are illustrated in Figure 5 depicting an ideal voltage/current characteristic of a fuel cell. The figure shows that as soon as current is supplied there is a sudden voltage drop in the system. This happens commonly in low temperature PEM fuel cells, as compared to high temperature cells [12]. This characteristic is useful especially in troubleshooting when something goes wrong with the fuel cell.

The region I is called activation losses $V_{\text {act. }}$. In region labelled II is ohmic vol- 
tage losses $V_{\text {ohm }}$, voltage drop is observed as linear; this suggests the resistive flow of protons. Region III is concentration losses $V_{\text {conc }}$ where another abrupt voltage drop is observed, mainly due to mass transport losses. These losses cause the cell voltage to become less than the ideal voltage, hence,

$$
V_{F C}=E_{\text {nernst }}-V_{\text {act }}-V_{\text {conc }}-V_{\text {ohmic }}
$$

where $E_{\text {nernst }}$ is the thermodynamic potential of the individual cell, $V_{\text {act }}$ is the loss due to the activation of the anode and cathode electrodes, $V_{\text {conc }}$ is the concentration loss while $V_{\text {ohmic }}$ is the ohmic loss.

\subsection{Nernst Voltage}

The resultant voltage of a fuel cell stack is the difference between the Nernst voltage $E_{\text {Nernst }}$ and the voltage loss $V_{\text {loss. }} E_{\text {nernst }}$ is given as [8]:

$$
E_{\text {nernst }}=E^{0}+\frac{R T}{2 F} \ln \left(\frac{P_{\mathrm{H}_{2}} \cdot\left(P_{\mathrm{O}_{2}}\right)^{1 / 2}}{P_{\mathrm{H}_{2} \mathrm{O}}}\right)
$$

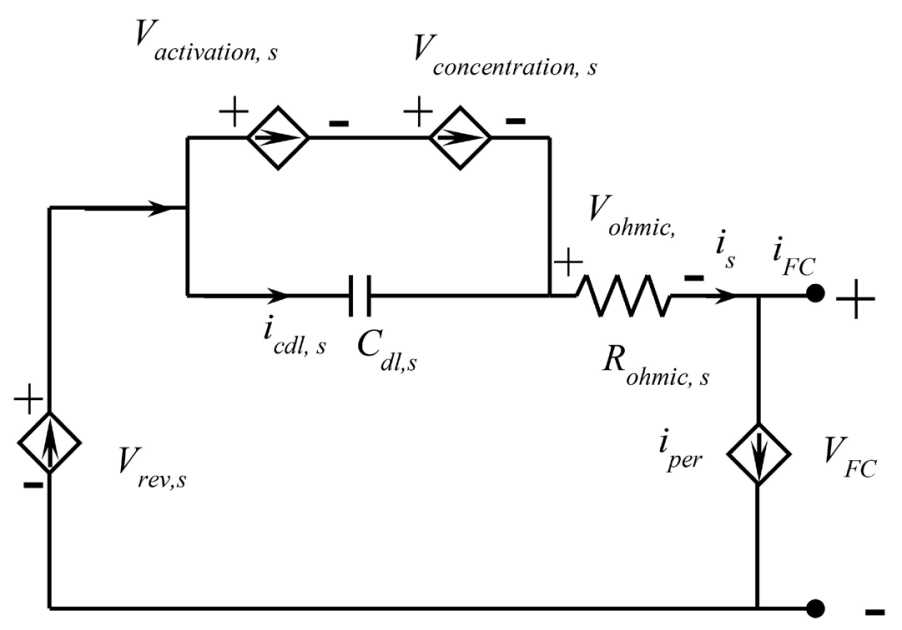

Figure 4. Electrical M schematic.

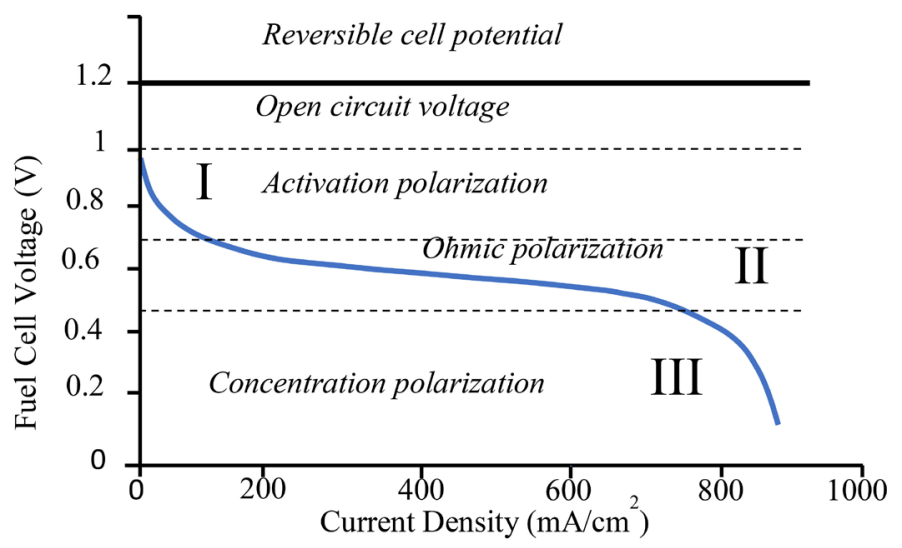

Figure 5. Ideal voltage vs current characteristic of fuel cell (Polarization curve) [10]. 
Since the by-product is assumed as liquid water, $P_{\mathrm{H}_{2} \mathrm{O}}$ at 1 atm so that Equation (2) becomes:

$$
E_{\text {nernst }}=E^{0}+\frac{R T}{2 F} \ln \left(P_{\mathrm{H}_{2}} \cdot\left(P_{\mathrm{O}_{2}}\right)^{1 / 2}\right)
$$

where $R$ is the ideal gas constant, $T$ is the temperature, $E^{0}$ is the standard-state reversible voltage at $1 \mathrm{~atm}, F$ is Faraday constant, and $P_{\mathrm{H}_{2}}, P_{\mathrm{H}_{2} \mathrm{O}}$, and $P_{\mathrm{O}_{2}}$ are the partial pressures of hydrogen, water and oxygen respectively.

\subsection{Activation Losses}

Activation losses are caused by the slowness of reactions on the surface of the electrodes [13]. Part of the voltage is lost to the chemical reaction in trying to force the electrons to the electrodes. These reactions need activation energy at both the anode and the cathode. Steady state activation losses are represented by [14]:

$$
\begin{aligned}
& V_{a c t}=-A \ln I_{f c} \\
& \text { and } A=\frac{R T}{z \alpha F}
\end{aligned}
$$

So that,

$$
V_{a c t}=-\frac{R T}{z \alpha F} \ln I_{f c}
$$

where $A$ is Tafel slope, $I_{f c}$ is the fuel cell current, $z$ is the number of moving electrons, $\alpha$ is the charge transfer coefficient which depends on the type of electrodes and catalyst used. Equation (6) is normally expressed empirically as [15]:

$$
V_{\text {act }}=\zeta_{1}+\zeta_{2} T_{\text {cell }}+\zeta_{3} T_{\text {cell }}\left[\ln \left(C_{\mathrm{O}_{2}}\right)\right]+\zeta_{4}\left[\ln \left(I_{f c}\right)\right]
$$

where $C_{\mathrm{O}_{2}}$ is the effective oxygen concentration, and it is given as [16]:

$$
C_{\mathrm{O}_{2}}=\frac{P_{\mathrm{O}_{2}}}{5.08 \times 10^{6} \times e^{\frac{498}{T_{\text {cell }}}}}
$$

The constants $\zeta_{1-4}$ are found experimentally and Equation (7) becomes:

$$
V_{\text {act }}=-0.9514+3.12 \times 10^{-3} T_{\text {cell }}+7.4 \times 10^{-5} T_{\text {cell }} \ln C_{\mathrm{O}_{2}}-1.87 \times 10^{-4} \ln \left(I_{f c}\right)
$$

Dynamic modelling will have to account for the effect of charge double layer (CDL) which is a charge on the surface of electrodes caused by contact between two materials [7]. This layer represents a store of electrical charge and would keep on changing with time, hence the use of a capacitor $\left(C_{d l}\right)$ in the modelling of the dynamic system. Referring to Figure 3, the equation in a dynamic mode can be given as:

$$
\begin{gathered}
V_{C d l}=V_{a c t 0}+V_{c o n c} \\
V_{c d l}=I_{f c} R_{C d l} \\
R_{C d l}=\frac{V_{a c t 0}+V_{c o n c}}{I_{f c}}
\end{gathered}
$$


But,

$$
\frac{\mathrm{d} V_{C d l}}{\mathrm{~d} t}=\frac{I_{f c}}{C_{d l}}-\frac{V_{C d l}}{R_{C d l} C_{d l}}
$$

and

$$
\frac{\mathrm{d} V_{C d l}}{\mathrm{~d} t}=\frac{I_{f c}}{C_{d l}}-\frac{V_{C d l}}{\left(\frac{V_{a c t 0}+V_{c o n c}}{I_{f c}}\right) C_{d l}}
$$

The magnitude of activation losses is determined by temperature, the higher the temperature the lower the activation losses [10].

\subsection{Ohmic Losses}

The ohmic overvoltage is normally caused by the membrane's resistance to the proton flow [10]. Ohmic resistance is a result of resistance in the polymer membrane and conduction resistance between the membrane and electrodes in the electrodes [8] The ohmic losses are therefore represented as:

$$
V_{\text {ohm }}=V_{\text {ohm }, a}-V_{\text {ohm, mebrane }}-V_{\text {ohm }, c}=I_{f c} R_{\text {ohm }}
$$

If $N$ is the number of cells Equation (15) then becomes:

$$
V_{o h m}=N\left(I_{f c} R_{o h m}\right)
$$

where $R_{M}$ which is the equivalent membrane resistance to the flow of electrons and $R_{c}$ is the equivalent resistance between the membrane and electrodes as well as the electrodes and the bipolar plates to the flow of protons [14]. Equation (16) can then be represented as:

$$
V_{\text {ohm }}=N\left(I_{\text {fc }} R_{\text {ohm }}\right)=N\left(I_{\text {fc }}\left(R_{M}+R_{c}\right)\right)
$$

where $R_{c}$ is a contact resistance constant and $R_{M}$ can be expressed from Ohm's law as:

$$
R_{M}=\frac{\gamma_{M} l}{A}
$$

Hence,

$$
V_{\text {ohm }}=N\left[I_{f c}\left(\frac{\gamma_{M} l}{A}+R_{c}\right)\right]
$$

and $\gamma_{M}$ which is the resistivity of the membrane (Nafion) can be calculated from [14]:

$$
\gamma_{M}=\frac{181.6\left[1+0.03\left(\frac{i}{A}\right)+0.062\left(\frac{T}{303}\right)^{2}\left(\frac{i}{A}\right)^{2.5}\right]}{\lambda-0.634-3\left(\frac{i}{A}\right) \exp \left[4.18\left\{\left(T-\left(\frac{303}{T}\right)\right)\right\}\right]}
$$

where $\lambda$ is water content of the membrane, $A$ is the area. 


\subsection{Concentration Losses}

There are some losses in a fuel cell due to mass transport and these are referred to as concentration losses. These losses can be reduced by optimizing mass transport in the flow field [16]. Slow transportation of reactants to the reaction sites causes concentration voltage drop at high current densities and the voltage concentration losses are given by [8]:

$$
V_{\text {conc }}=\frac{R \times T}{Z \times F} \ln \left(1-\frac{I_{f c}}{I_{\text {limit }}}\right)
$$

where $I_{\text {limit }}$ is the limitation current, it is the maximum current density that causes a sharp voltage drop. With $N$ number of cells connected, the equation becomes,

$$
V_{\text {conc }}=N\left[\frac{R \times T}{Z \times F} \ln \left(1-\frac{I_{f c}}{I_{\text {limit }}}\right)\right]
$$

\subsection{Partial Pressures of the Anode and the Cathode}

The fuel cell voltage potential increases with increase in the partial pressures of the reactants and a decrease of the products [14].

Partial pressures of hydrogen and oxygen at the anode and the cathode are respectively given by [8]:

$$
\begin{gathered}
P_{\mathrm{H}_{2}}=0.5 P_{\mathrm{H}_{2} \mathrm{O}}^{\text {sat }}\left[\mathrm{e}\left(-\frac{1.635 \mathrm{~J}}{T_{\text {cell }}^{1.334}}\right) \times \frac{P_{a}}{P_{\mathrm{H}_{2} \mathrm{O}}^{\text {sat }}}-1\right] \\
P_{\mathrm{O}_{2}}=P_{\mathrm{H}_{2} \mathrm{O}}^{\text {sat }}\left[\mathrm{e}\left(-\frac{4.192 \mathrm{~J}}{T_{\text {cell }}^{1.334}}\right) \times \frac{P_{c}}{P_{\mathrm{H}_{2} \mathrm{O}}^{\text {sat }}}-1\right]
\end{gathered}
$$

where,

$P_{a}=$ Partial pressure for anode, $J=$ Current density, $P_{c}=$ Partial pressure for cathode and $P_{\mathrm{H}_{2} \mathrm{O}}^{\text {sat }}=$ Saturation pressure for water and this is found from [17]:

$$
\begin{gathered}
\log _{10}\left(P_{\mathrm{H}_{2} \mathrm{O}}^{\text {sat }}\right)=-2.18+2.95 \times 10^{-2} T_{c}-9.18 \times 10^{-5} T_{c}^{2}+1.44 \times 10^{-7} T_{c}^{3} \\
P_{\mathrm{H}_{2} \mathrm{O}}^{\text {sat }}=10^{\left(-2.18+2.95 \times 10^{-2} T_{c}-9.18 \times 10^{-5} T_{c}^{2}+1.44 \times 10^{-7} T_{c}^{3}\right)}
\end{gathered}
$$

\subsection{Fuel Cell Power and Efficiency}

Fuel cell efficiency can be defined as the ratio between the cell output voltage and the theoretical cell voltage. This can also be defined as the ratio between the electricity produced and hydrogen produced [18].

$$
\eta_{f c}=\frac{W_{e l}}{W_{\mathrm{H}_{2}}}
$$

$W_{e l}$ is the electricity produced and $W_{\mathrm{H}_{2}}$ is the energy value of hydrogen consumed in watts.

$$
W_{e l}=I \times V,
$$

According to Faraday's law hydrogen consumed $\left(N_{\mathrm{H}_{2}}\right)$ is proportional to 
current produced,

$$
\begin{gathered}
N_{\mathrm{H}_{2}}=\frac{I}{n F} \\
\text { and } W_{\mathrm{H}_{2}}=\Delta H \frac{I}{n F}
\end{gathered}
$$

where $\Delta H$ is hydrogen's higher heating value (HHV) $(286 \mathrm{~kJ} / \mathrm{mol})$. $\mathrm{HHV}$ has a value of 1.482 and is employed in this model because the fuel cell is a low temperature one [18]. Substituting Equations (28) to (30) into Equation (27) gives:

$$
\eta_{f c}=\frac{V_{c}}{1.482}
$$

where $V_{c}$ is the fuel cell voltage and $\eta_{f c}$ is the efficiency.

\subsection{The Simulink Model}

Figure 6 depicts the Simulink model which comprises of several subsystems. The inputs to the model are on the left side. The inputs include current density, membrane area, temperature of the cell, fuel cell current, limiting current, gas constant $(R)$ and Faraday constant.

The model is designed to predict the fuel cell characteristics such as voltage variations, efficiency and power by solving Equations (1)-(31). The main subsystems include the concentration voltage loss, ohmic voltage loss, activation voltage loss, dynamic voltage loss, efficiency and power. This model is able to predict the fuel cell potential response due to sudden changes in the current loads. The model also predicts the variations in the system efficiencies and power.

\section{Results and Discussions}

\section{Efficiency}

Figure 7 shows the efficiency from experimental analysis of this system. The efficiency starts at about $50 \%$ and decreases as the system is being run. It stabilizes at around $28 \%$ and decreases at a steady rate to about $20 \%$. The reason for decreasing at the end could have been the reduction in pressure from the canister as hydrogen is being utilized.

The potential of cells and the electric current are interrelated by polarization curves. Figure 8 depicts polarization curves for the model and the experimental results at a fuel cell temperature of $45^{\circ} \mathrm{C}$. The values obtained in the Simulink model display a smooth graph that starts with high values of voltage at lower currents. There is some degree of similarity of the graphs to the general polarization curve (Figure 5) especially regarding the activation and ohmic polarization. The electrochemical losses are based on these polarizations as shown in Equation (1). The model and experimental graphs show similar behavior except that the experimental graph has lower values of voltages at similar currents. For example, at current densities of 0.1 and $0.2 \mathrm{~A} / \mathrm{cm}^{2}$, the voltages are respectively 43 $\mathrm{V}$ and $40.5 \mathrm{~V}$ for the model. The corresponding values from experiment are $33 \mathrm{~V}$ 
and $28 \mathrm{~V}$ respectively.

Figure 9 shows the polarization curves at different fuel cell operating temperatures. There is good agreement between the model and experimental results at temperatures of $24^{\circ} \mathrm{C}, 30^{\circ} \mathrm{C}$ and $34^{\circ} \mathrm{C}$.

The figure also shows that as temperature increases there is an upward shift of the polarization curve. The cell potential increases as the temperature increases in that range of $24^{\circ} \mathrm{C}$ to $34^{\circ} \mathrm{C}$. This shows that within this range the fuel cell performs better at a higher temperature. These results can be compared to results achieved by [11] who also explored the effects of different conditions.

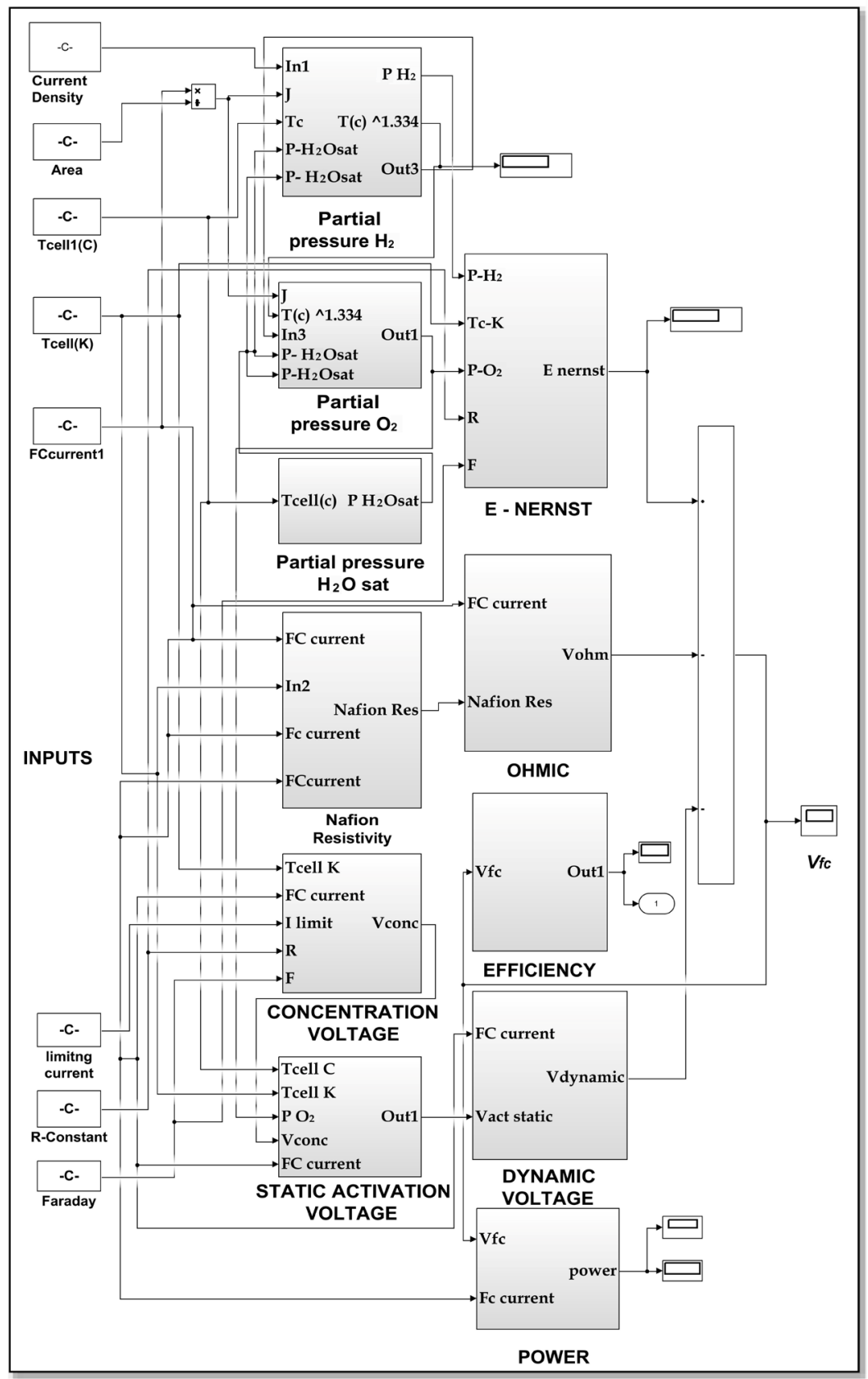

Figure 6. PEMFC Simulink model. 


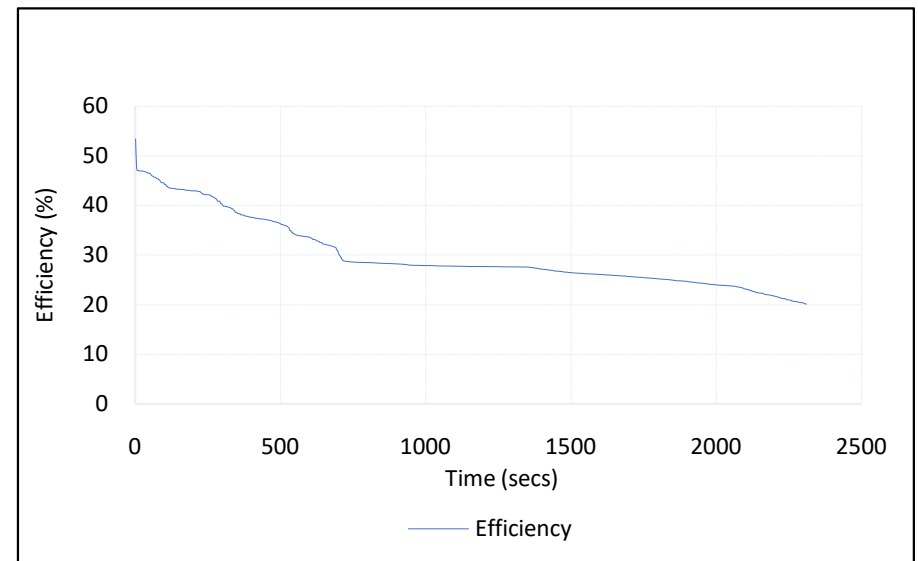

Figure 7. Efficiency profile.

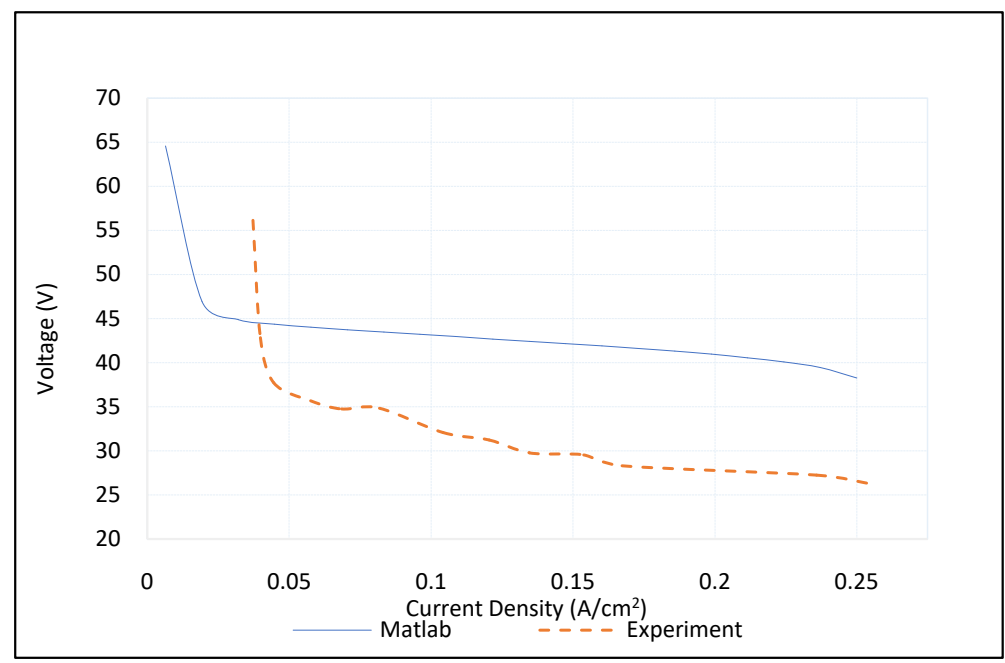

Figure 8. Polarization curves.

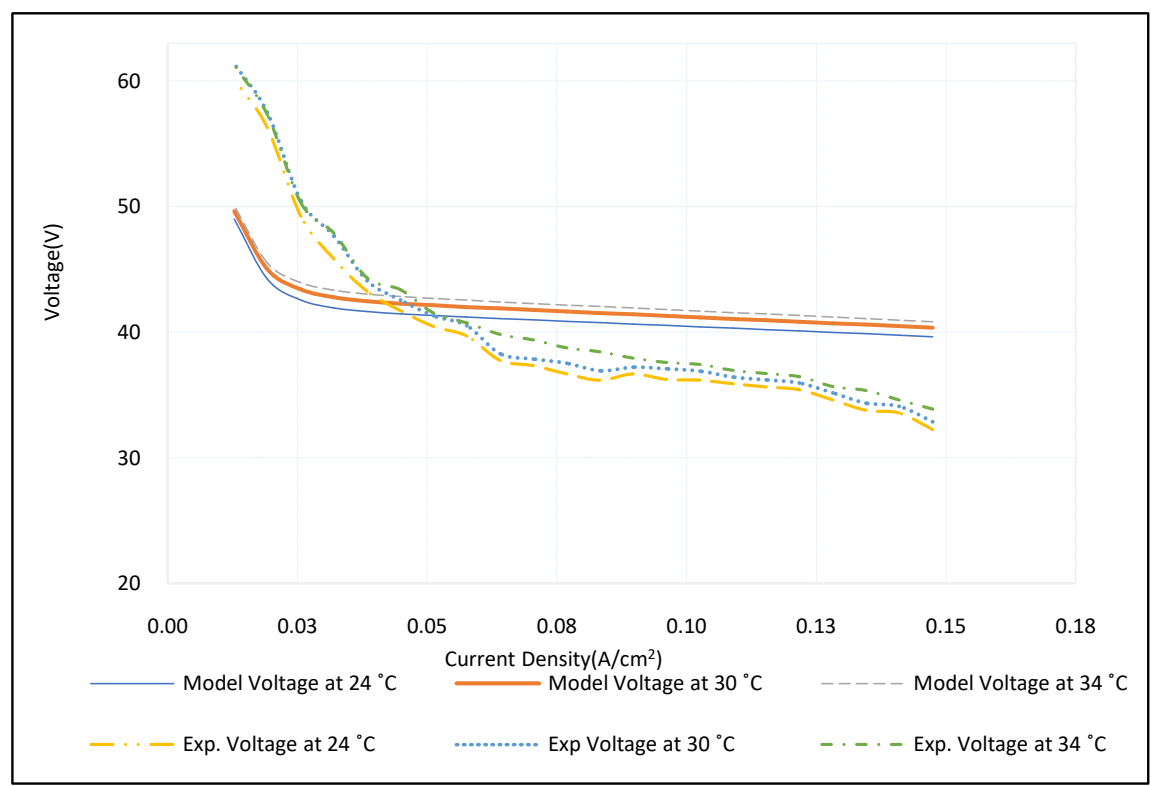

Figure 9. Polarization curves at different temperatures. 
Figure 10 depicts variations of purge temperature and fuel cell temperature with respect to time as the fuel cell is operated at a constant pressure and current (from experiments). The purge temperature is the temperature of hydrogen flowing out of the cell. The purge temperature is seen decreasing while the fuel cell temperature increases. This is a parallel heat exchanger type of behavior. It is not surprising as the hydrogen travels through the channels hence exchanging heat with fuel cell components. The reactions inside the fuel cell are exothermic therefore thermal energy is liberated heating up the cells. The air coolant plays a major part in reducing the purge temperature and keeping the fuel cell temperature flat as the system continues to run.

Figure 11 shows the relationship between the fuel cell power and current. The experimental results are juxtaposed to the model results and nearly perfect agreement was observed between them. The power data from the experiment was acquired by increasing the current load at intervals and therefore power was recorded at those intervals of the load.

Comparison between experimental fuel cell temperature and power and the Simulink model predictions are shown in Figure 12. As current is increased the fuel cell power increases as well. The experiments and the model show that as the current increases the temperature decreases and the power decreases.

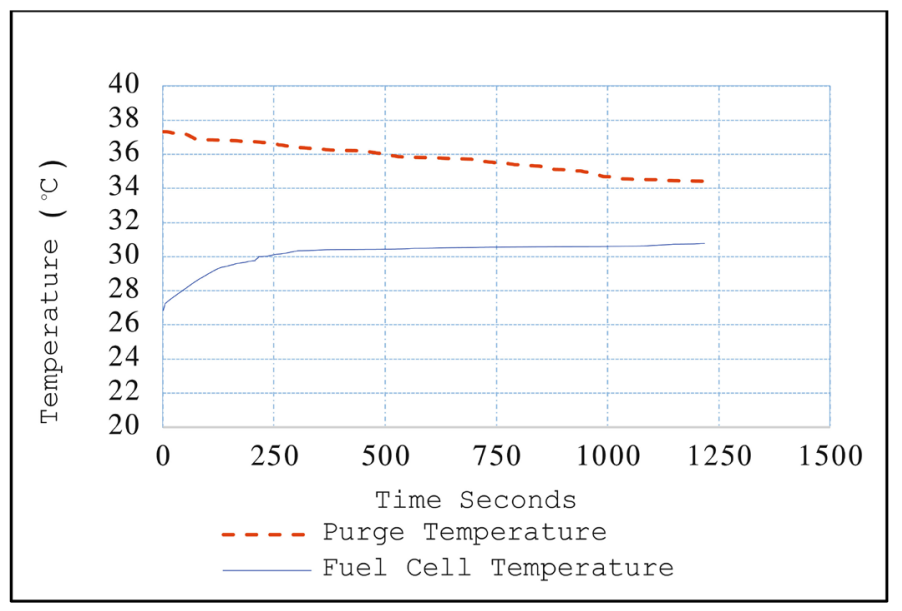

Figure 10. Temperature variations with time.

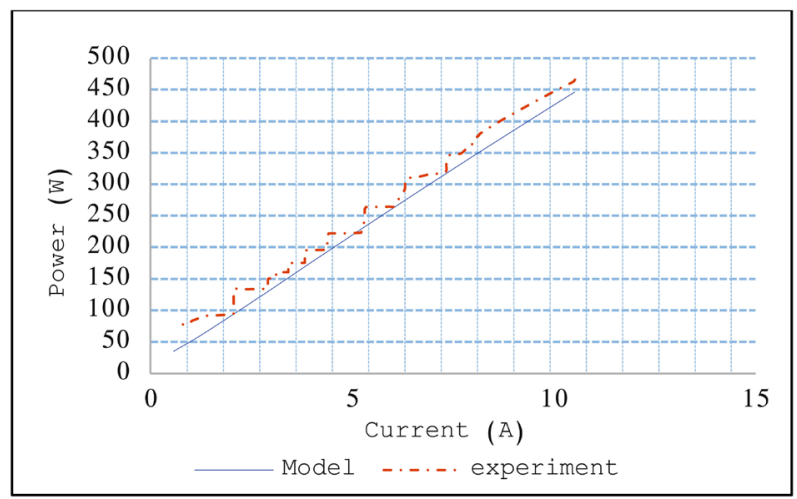

Figure 11. Power vs current curves. 


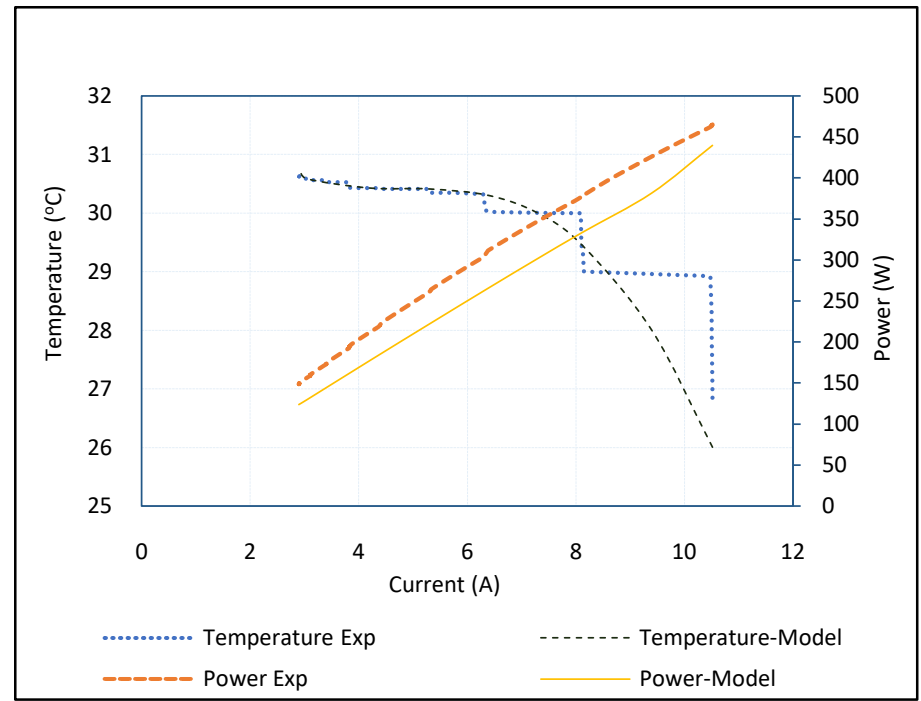

Figure 12. Temperature, Power against current.

\section{Model Limitations and Future Work}

Although the model can predict the performance of the fuel cell in terms of efficiencies and power output, the model can be expanded to cover other areas of simulations. There is an opportunity to include thermal simulations in this model to study heat transfer especially in low temperature operation. As this is a model designed for low temperature operations, future work would consider high temperature fuel cell simulations. There are some differences between the experimental and model which

\section{Conclusion}

This paper is based on an experimental work and a Matlab/Simulink model of EC6C fuel cell by Edibon. The experiments were used to validate the electrical model implemented in Simulink. Several experiments were carried out which included determination of efficiency, polarization curves, temperature, potential and power. The experiments demonstrated the performance of the system. The Simulink model predicted the electrical response to changing parameters like loads. A comparison was made between the experimental results and the fuel cell model. The experimental output shows good agreement with the model. This proves that graphical output from experiments validates the simulation model response to parameters. It is concluded that the model having the ability to predict fuel cell response to various inputs can be used in optimization processes for the fuel cell.

\section{Highlights}

- Harmful emissions form combustion of fossil fuels justifies the need for research in alternative technologies.

- Proton Exchange Membrane Fuel Cell is promising technologies. 
- Mathematical Modelling of PEMFC is instrumental in optimization of fuel cell.

- Fuel cells have high efficiencies compared to other competing technologies.

\section{Conflicts of Interest}

The authors declare no conflicts of interest regarding the publication of this paper.

\section{References}

[1] Litster, S. and McLean, G. (2004) PEM Fuel Cell Electrodes. Journal of Power Sources, 3, 61-76. https://doi.org/10.1016/j.jpowsour.2003.12.055

[2] Panayiotou, G., Kalogirou, S. and Tassou, S. (2010) PEM Fuel Cells for Energy Production in Solar Hydrogen Systems. Recent Patents on Mechanical Engineering, 3, 226-235. https://doi.org/10.2174/2212797611003030226

[3] Haille, M.S. (2003) Fuel Cell Materials and Components. Acta Materialia, 51, 59816000. https://doi.org/10.1016/j.actamat.2003.08.004

[4] Saadi, A., Becherif, M., Hissel, D. and Ramadan, H. (2017) Dynamic Modeling and Experimental Analysis of PEMFCs: A Comparative Study. International Journal of Hydrogen Energy, 42, 1544-1557. https://doi.org/10.1016/j.ijhydene.2016.07.180

[5] Nguyena, G., Sahlinb, S., Andreasenb, S., Shaffera, B. and Brouwer, J. (2016) Dynamic Modeling and Experimental Investigation of a High Temperature PEM Fuel Cell Stack. International Journal of Hydrogen Energy, 41, 4729-4739.

https://doi.org/10.1016/j.ijhydene.2016.01.045

[6] Zaidi, A., Pooja Pokharkar, P., Krishnan, R. and Sonawane, D. (2014) Dynamic Modeling and Simulation of A PEM Fuel Cell: MATLAB and Lab VIEW Modeling Approach. International Conference on Non-Conventional Energy, Pune, 272-276. https://doi.org/10.1109/ICONCE.2014.6808744

[7] Azri, M., Mubin, A.N., Ibrahim, Z., Rahim, N.A. and Raihan, S.R. (2016) Mathematical Modelling for Proton Exchange Membrane Fuel Cell (PEMFC). Journal of Theoretical and Applied Information Technology, 86, 409-419.

[8] Monem, A., Azmy, A. and SA, M. (2014) Dynamic Modelling of Proton Exchange Membrane Fuel Cells for Electric Vehicle Applications. Journal of Petroleum \& Environmental Biotechnology, 5, Article ID: 1000169.

https://doi.org/10.4172/2157-7463.1000169

[9] Edwards, R. and Demuren, A. (2016) Regression Analysis of PEM Fuel Cell Transient Response. International Journal of Energy and Environmental Engineering, 7, 329-341. https://doi.org/10.1007/s40095-016-0209-1

[10] Martín, I., Ursúa, A. and Sanchis, P. (2014) Modelling of PEM Fuel Cell Performance: Steady-State and Dynamic Experimental Validation. Energies, 7, 670-700.

https://doi.org/10.3390/en7020670

[11] Abdin, Z., Webb, C. and Gray, E. (2016) PEM Fuel Cell Model and Simulation in Matlab Simulink Based on Physical Parameters. Energy, 116, 1131-1144. https://doi.org/10.1016/j.energy.2016.10.033

[12] Edibon Practical Exercises Manual, EC6C, 2015. pp 1-102, Madrid, Spain.

[13] Liso, V., Nielsen, M., Kær, S. and Mortensen, H. (2014) Thermal Modeling and Temperature Control of a PEM Fuel Cell System for Forklift Applications. International Journal of Hydrogen Energy, 39, 8410-8420. 
https://doi.org/10.1016/j.ijhydene.2014.03.175

[14] Sharma, K. and Priyadarshini, N. (2012) A Dynamic Modeling and Simulation of a Proton Exchange Membrane Fuel Cell Using MATLAB/SIMULINK. ICAE 2012, Rajasthan, 109-115.

[15] Fournier, M., Agbossou, K., Poulin, A. and Dubé, Y. (2006) Dynamic Model of a PEMFC Stack Suitable for Component Level Modeling of a Fuel Cell-Based Generator. WHEC 16, Lyon, 13-16 June 2006, 1-12.

[16] Jung, J. and Ahmed, S. (2010) Dynamic Model of PEM Fuel Cell Using Real-Time Simulation Techniques. Journal of Power Electronics, 10, 739-748.

https://doi.org/10.6113/JPE.2010.10.6.739

[17] O’hayre, R., Cha, S., Colella, W. and Prinz, F.B. (2009) Fuel Cell Fundamentals. 2nd Edition, John Wiley \& Sons, Hoboken.

[18] Barbir, F. (2005) PEM Fuel Cells. Academic Press, University of Split, Split, 33-72. https://doi.org/10.1016/B978-012078142-3/50004-5 